\title{
SEXUALITY AND KNOWLEDGE ABOUT HIV/AIDS IN ELDERS WHO PARTICIPATE IN A SOCIAL CENTER FOR THE ELDERLY
}

\author{
SEXUALIDADE E CONHECIMENTO SOBRE HIV/AIDS DE IDOSO \\ PARTICIPANTES DE UM CENTRO DE CONVICENCIA PARA IDOSOS
}

\author{
Bruna Stephanie Sousa MALAQUIAS ${ }^{1}$; Giovanna Gaudenci NARDELLI ${ }^{2}$; \\ Nayara Freitas AZEVEDO ${ }^{3}$; Carolina Silva LEDIC ${ }^{4}$; Eliana Maria GAUDENCI ${ }^{5}$; \\ Álvaro da Silva SANTOS
}

1. Enfermeira, Mestranda em Atenção à Saúde pela Universidade Federal do Triângulo Mineiro - UFTM, Uberaba, MG, Brasil; 2. Enfermeira, Especialista em Saúde da Família pelo Centro Universitário Internacional - UNINTER, Curitiba, PR, Brasil, Mestranda em Atenção à Saúde pela UFTM, Uberaba, MG, Brasil. giovanna.gnardelli@ gmail.com; 3. Graduanda em Enfermagem pela UFTM, Uberaba, MG; 4. Graduanda em Educação Física pela UFTM, Uberaba, MG; 5. Professora, Mestre, Instituto de Ciência da Saúde, UFTM, Uberaba, MG; Professor, Doutor, Instituto de Ciência da Saúde, UFTM, Uberaba, MG

\begin{abstract}
The objective of this study was to analyze the knowledge of elders regarding HIV/AIDS and the sexual quotient of both genders in a Social Center in a town in the countryside of Minas Gerais, Brazil. This is a descriptive, transversal and quantitative study, involving 457 elders who belong to social groups offered by the Facility for the Care of the Elderly (UAI, in the Portuguese acronym), in the town of Uberaba, MG. In this study, the following instruments were used: MEEM to select those with a minimum level of cognition, QHIV3I to evaluate their knowledge, and QS-F/QS-M to measure the sexual quotient. Data was analyzed with the "Statistical Package for Social Sciences" (SPSS), version 20.0. Females represented $74 \%$ of participants, $40.5 \%$ between 70 and 79 y/o. $51.8 \%$ stated not to have a partner. Questions regarding transmission by needles and syringes, had the greatest number of right answers $96.2 \%$. Only $45.1 \%$, however, answered correctly the question about transmission through mosquito bites. $90.2 \%$ of the elders know it is possible to detect the virus through laboratory exams. And $88.2 \%$ of them stated to have never used a condom in sexual intercourses. Regarding the sexual quotient, $57.7 \%$ of the female elders stated to have a bad or null sex life, while only $7.6 \%$ of the male stated to have inactive sex lives. Campaigns targeted at this population are necessary, as well as an increase in the awareness of the health professionals, since that would make it possible for them to recognize the sexuality of the elder, and the risks inherent to it.
\end{abstract}

KEYWORDS: Sexuality. HIV. Aged.

\section{INTRODUCTION}

Populational aging is a global phenomena, and in Brazil, it is a part of changes in health indicators. It can be noted through the fall in mortality and fecundity rates, in the increase in life expectancy and the technological development in the treatment of illnesses, especially Chronic NonCommunicable Diseases (CNCD). Even though an increased life expectancy is indicative of better living conditions, aging must be considered according to indicators of quality of life (KALACHE, VERAS, 1987; CIOSAK et al, 2011).

In 2003, the Statute of the Elderly was approved by the Ministry of Health (MS), securing to the elderly an easy access to every opportunity to preserve their physical and mental health. Policies focused on the aging process have aimed at promoting health, and the approach of questions related to sexuality has proven itself to be invaluable (BRASIL, 2007; SÃO PAULO, 2011).

Sexuality is an inherent component to life, a continuous process which starts before birth and is only concluded with death (GALATI, 2014). Its structure is influenced by biological, physiological, emotional, social and cultural factors, which resonate in the life and health of human beings (SILVEIRA, 2014). Sexuality is also important for the individual to communicate with himself and with other people, and as such it exerts an influence in the way people act and position themselves in the world around them (GALATI, 2014).

When related to the aging process, sexuality brings in its wake myths and taboos which need to be surmounted, and those end up discouraging these people's sexual lives, since in our society it is not culturally accepTable for people to have sexual intercourse after a certain age, and the practice is understood as abnormal, shameful and immoral (ALENCAR, 2014). Healthy sexuality acquires a fundamental role in the life of the elderly. Elderly women and men need support with certain difficulties specific to them, and measures aiming at promoting their quality of life as they age, and at surmounting the taboos which surround sexuality in older ages (FLEURY, 2013; ALENCAR, 2014). 
Few campaigns regarding Sexually Transmitted Diseases (TDSs) are aimed at the elderly, and that fact coupled with their general prejudice against the use of condoms and their increasing sexual activity, means that an important part of the population is exposed to the risk of contracting infections through HIV (Human Immunodeficiency Virus). Not to mention that health professionals are not adequately trained to promptly diagnose STDs in people from this age group, in which, generally, chronic-degenerative diseases are predominant (BEAULAURIE, CRAIG, DE LA ROSA, 2009).

Therefore, while a diminishing in the number of AIDS (Acquired Immunodeficiency Syndrome) victims is verified among people who belong to younger age groups, a significant growth in that number is reported among the elderly. According to data from the Ministry of Health (MS), the number of elders affected by HIV has grown over $80 \%$ in the last 12 years, thanks mostly to the increase in their sexual activity, and the fact that they do not use condoms (MINAS GERAIS, 2014).

Most young people and health professionals have a certain level of knowledge about HIV, while usually little information is offered to the elderly. Thus, the objective of this study was to assess the knowledge of the elders regarding HIV/AIDS and the sexual quotient o both genders in a Social Center in a city in the countryside of Minas Gerais, Brazil.

\section{MATERIAL AND METHODS}

This is a descriptive, transversal and quantitative study, made with elders who belong to social groups offered by the Facility for the Care of the Elderly (UAI, in the Portuguese acronym), in the town of Uberaba, MG.

The population of this study was composed by elders who actively participate in the social groups and other activities made available by the UAI. From the 950 elders who fit the inclusion criteria, according to data made available by the offices in the facility, research has obtained answers from $48.1 \%$ (457). The frequency with which some elders were absent from the activities can be considered as one of the main reasons for the sample losses, as well as refusals to participate in the research, and removal of the elders' register in the UAI during the data collection.

Data collection happened between September and November of 2015, and was constituted by the following stages: the elders were contacted before or after the activities, an explanation about the research was given to them, including its objectives and that participation was optional; after that, an Informed Consent Form was signed by the elder. After that, a Mini-mental was filled (MEEM), and if the elder reached the minimum score, he or she was invited to fill a questionnaire regarding their knowledge about HIV/AIDS (QHIV3I) and another instrument regarding sexual quotient, the Sexual Quotient instrument, which is different for each gender (male/female). Both instruments, the QHIV3I and the SQ, are validated in Brazil (ABDO, 2006; LOZZAROTTO, 2008).

Data was managed through the use of the software Excel ${ }^{\circledR} 2013$, and analyzed using the Statistical Package for Social Sciences (SPSS), version 20.0. Data went through exploratory analysis through simple and absolute frequency, and percentages for the categorical variables. The analysis of the results of the sexual quotient questionnaires used the score established by the questionnaire itself, which varies from 0 to 100 .

It is important to notice that this research was conducted according to the demands of the Resolution 466/12, of the National Council of Health ${ }^{10}$, and it was approved by the Research Ethics Committee in the Federal University in the Triângulo Mineiro, through the Plataforma Brasil, CAAE number 47386515.9.0000.5154.

\section{RESULTS}

From the 950 elders who constituted the target population, 457 participated in the study $(51 \%), 74 \%$ of those females $(n=338)$ and $26 \%$ of those male $(\mathrm{n}=119)$. Most of the elders interviewed was between 60 and 69 years old $(48.7 \%$ of men and $50.6 \%$ of women). $59.2 \%$ of the elder women have stated not to have a partner, while $68.1 \%$ of men have said to have a partner. Regarding education, $36.1 \%$ of the females and $28.6 \%$ of the males in the research studied between 4 and 7 years, while $5.3 \%$ of females and $7.6 \%$ of males studied for over 12 years. Regarding monthly income, $57.1 \%$ of females reported monthly income of less than one minimum wage, while $48.7 \%$ of males reported an income between 1 and 3 minimum wages. Regarding religion, most participants (63.6\%) were catholic, including both genders (Table 1). 
Table 1. Sociodemographic data divided by gender. Uberaba - MG, 2016.

\begin{tabular}{|c|c|c|c|c|}
\hline & $\begin{array}{l}\text { Male } \\
(n=119)\end{array}$ & & & \\
\hline Variables & $\mathbf{N}$ & $\%$ & $\mathbf{N}$ & $\%$ \\
\hline \multicolumn{5}{|l|}{ Age Group } \\
\hline 60 to $69 \mathrm{y} / \mathrm{o}$ & 58 & 48.7 & 171 & 50.6 \\
\hline 70 to $79 \mathrm{y} / \mathrm{o}$ & 45 & 37.8 & 141 & 42.6 \\
\hline Above $80 \mathrm{y} / \mathrm{o}$ & 16 & 13.5 & 23 & 6.8 \\
\hline \multicolumn{5}{|l|}{ Marital Status } \\
\hline Has a partner & 81 & 68.1 & 136 & 40.2 \\
\hline Does not have a partner & 37 & 31.1 & 200 & 59.5 \\
\hline Did not respond & 1 & 0.8 & 2 & 0.6 \\
\hline \multicolumn{5}{|l|}{ Education } \\
\hline None & 19 & 16 & 32 & 9.5 \\
\hline 1 to 3 years & 23 & 19.3 & 101 & 29.9 \\
\hline 4 to 7 years & 34 & 28.6 & 122 & 36.1 \\
\hline 8 to 11 years & 33 & 27.7 & 61 & 18.0 \\
\hline 12 years or more & 9 & 7.6 & 18 & 5.3 \\
\hline Did not respond & 1 & 0.8 & 4 & 1.2 \\
\hline \multicolumn{5}{|l|}{ Income } \\
\hline Up to 1 minimum wage & 40 & 33.6 & 193 & 57.1 \\
\hline 1 to 3 minimum wages & 58 & 48.7 & 118 & 34.9 \\
\hline 4 to 6 minimum wages & 15 & 12.6 & 18 & 5.3 \\
\hline 7 to 10 minimum wages & 3 & 2.5 & 2 & 0.6 \\
\hline Above 10 minimum wages & 2 & 1.7 & 1 & 0.3 \\
\hline Did not respond & 1 & 0.8 & 6 & 1.8 \\
\hline \multicolumn{5}{|l|}{ Religion } \\
\hline Catholic & 74 & 62.2 & 216 & 63.9 \\
\hline Spiritualism & 24 & 20.2 & 63 & 18.6 \\
\hline Protestantism & 8 & 6.7 & 32 & 9.5 \\
\hline Other & 4 & 3.4 & 18 & 5.3 \\
\hline Did not respond & 9 & 7.6 & 9 & 2.7 \\
\hline TOTAL & 119 & 100 & 338 & 100 \\
\hline
\end{tabular}

Regarding the questionnaire on the knowledge about HIV/AIDS (QHIV3I), most participants (96.2\% of females and $97.5 \%$ of males) got right the question regarding the transmission of AIDS through the use of the same syringe by different people (Q9). The lowest rate of right answers by female participants $(45.3 \%)$ was in the question regarding the transmission of AIDS by mosquito bite (Q6), and among male participants, the lowest right answer rate (49.6\%) was regarding the question about whether someone with the virus always presents symptoms of it (Q2).

Regarding the use of condoms, 298 female elders $(88.2 \%)$ and 62 male elders $(52.1 \%)$, said that they do not use the condoms, although $88.1 \%$ and $89.4 \%$ related, respectively, that they should be worried about being contaminated by HIV/AIDS and that condoms prevent that from happening. Regarding the conduction of the exam for AIDS,
$49.6 \%$ of the male and $62.4 \%$ of the female related have never undergone a test for the detection of AIDS (Table 2).

Regarding sexual activity, $57.7 \%$ of the female elders have stated to not be sexually active, while the rate of inactive sexual life falls to $7.6 \%$ among the male elders. Regarding questions about the will and stimuli to perform sexual intercourse at other moments, in other days or when given other opportunities, it was noticed that $69.2 \%(n=234)$ of femalerespondents answered "never", while 54.6\% $(n=65)$ of the male respondents answered "always". Analyzing the quotient scores, it was noticed that, regarding female participants, $64.2 \%$ of respondents presented a score between "Null to bad", and regarding man, only $11.8 \%$ presented this score, most of them, $46.2 \%$, achieving the score "Good to excellent" (Table 3). 
Table 2. Perception of the Elders regarding HIV/AIDS according to the QHIV3I, Uberaba - MG, 2016.

\begin{tabular}{|c|c|c|c|c|c|}
\hline & Male & & Female & & Rate of right answers \\
\hline Variables & $\mathbf{N}$ & $\%$ & $\mathbf{N}$ & $\%$ & $\%$ \\
\hline 1. HIV virus as a causa for AIDS & & & & & 88.7 \\
\hline True & 105 & 88.2 & 302 & 89.3 & \\
\hline False & 5 & 4.2 & 10 & 3 & \\
\hline Do not know & 8 & 6.7 & 25 & 7.4 & \\
\hline $\begin{array}{l}\text { 2. A person with the virus always } \\
\text { manifests symptoms }\end{array}$ & & & & & 41.5 \\
\hline True & 59 & 49.6 & 146 & 43.2 & \\
\hline False & 45 & 37.8 & 153 & 45.3 & \\
\hline Do not know & 14 & 11.8 & 38 & 11.3 & \\
\hline 3. Laboratory exams & & & & & 88.8 \\
\hline True & 104 & 87.4 & 305 & 90.2 & \\
\hline False & 3 & 2.5 & 18 & 5.3 & \\
\hline Do not know & 11 & 9.2 & 12 & 3.6 & \\
\hline 4. Transmission through soap... & & & & & 75.8 \\
\hline True & 22 & 18.5 & 67 & 19.8 & \\
\hline False & 90 & 75.6 & 256 & 76 & \\
\hline Do not know & 6 & 5 & 14 & 3.9 & \\
\hline 5. Transmission by hug, kiss... & & & & & 78.6 \\
\hline True & 24 & 20.2 & 53 & 15.7 & \\
\hline False & 90 & 75.6 & 276 & 81.7 & \\
\hline Do not know & 4 & 3.4 & 6 & 1.8 & \\
\hline 6. Transmission by mosquito bite & & & & & 45.7 \\
\hline True & 56 & 47.1 & 122 & 36.1 & \\
\hline False & 55 & 46.2 & 153 & 45.3 & \\
\hline Do not know & 7 & 5.9 & 60 & 17.8 & \\
\hline 7. Condom prevents transmission & & & & & 89.4 \\
\hline True & 111 & 93.3 & 289 & 85.5 & \\
\hline False & 6 & 5 & 38 & 11.2 & \\
\hline Do not know & 1 & 0.8 & 9 & 2.7 & \\
\hline 8. Female condom & & & & & 86.0 \\
\hline True & 103 & 86.6 & 289 & 85.5 & \\
\hline False & 7 & 5.9 & 12 & 3.6 & \\
\hline Do not know & 8 & 6.7 & 35 & 10.4 & \\
\hline $\begin{array}{l}\text { 9. Transmission through syringes } \\
\text { and needles }\end{array}$ & & & & & 96.4 \\
\hline True & 115 & 96.6 & 325 & 96.2 & \\
\hline False & 1 & 0.8 & 8 & 2.4 & \\
\hline Do not know & 2 & 1.7 & 3 & 0.9 & \\
\hline 10. Only in homosexuals... & & & & & 86.3 \\
\hline True & 18 & 15.1 & 23 & 6.8 & \\
\hline False & 97 & 81.5 & 308 & 91.1 & \\
\hline Do not know & 3 & 2.5 & 5 & 1.5 & \\
\hline $\begin{array}{l}\text { 11. Elders do not need to worry } \\
\text { about AIDS }\end{array}$ & & & & & 88.1 \\
\hline True & 13 & 10.9 & 32 & 9.5 & \\
\hline False & 103 & 86.6 & 303 & 89.6 & \\
\hline Do not know & 2 & 1.7 & 1 & 0.3 & \\
\hline 12. AIDS has treatment & & & & & 90.0 \\
\hline True & 109 & 91.6 & 299 & 88.5 & \\
\hline False & 7 & 5.9 & 30 & 8.9 & \\
\hline Do not know & 2 & 1.7 & 7 & 2.1 & \\
\hline 13. AIDS has a cure & & & & & 74.6 \\
\hline
\end{tabular}




$\begin{array}{lrrrrr}\text { True } & 24 & 20.2 & 41 & 12.1 & \\ \text { False } & 86 & 72.3 & 260 & 76.9 & \\ \text { Do not know } & 8 & 6.7 & 35 & 10.4 & 80.4 \\ \text { 14. AIDS is a punishment from } & & & & & \\ \text { God } & 23 & 19.3 & 38 & 11.2 & \\ \text { True } & 91 & 76.5 & 285 & 84.3 & \\ \text { False } & 4 & 3.4 & 13 & 3.8 & - \\ \text { Do not know } & & & & & - \\ \text { 15. Knows someone who has AIDS } & 80 & 67.2 & 204 & 60.4 & \\ \text { Yes } & 38 & 31.9 & 131 & 38.8 & \\ \text { No } & & & & & \\ \text { 16. Wears condom } & 25 & 21 & 16 & 4.7 & \\ \text { Always } & 18 & 15.1 & 10 & 3 & \\ \text { Sometimes } & 3 & 2.5 & 0 & 0 & \\ \text { Rarely } & 62 & 52.1 & 298 & 88.2 & \\ \text { Never } & & & & & \\ \text { 17. Have undergone an AIDS exam } & 59 & 49.6 & 124 & 36.7 & \\ \text { Yes } & 59 & 49.6 & 211 & 62.4 & \\ \text { No } & & & & \end{array}$

Table 3. Score results of the sexual Quotient male and female participants, Uberaba - MG, 2016.

\begin{tabular}{lrrrr}
\hline \multicolumn{1}{c}{ Male } & \multicolumn{3}{c}{ Female } \\
\hline Variables & N & \% & N & \% \\
\hline Sexual Quotient & & & & \\
Null to bad & 14 & 11.8 & 217 & 64.2 \\
Bad to not favorable & 3 & 2.5 & 11 & 3.3 \\
Not favorable to & 9 & 7.6 & 26 & 7.7 \\
regular & & 31.9 & 33 & \\
Regular to good & 38 & 46.2 & 51 & 15.2 \\
Good to excellent & 55 & 100 & 338 & 100 \\
Total & 119 & & & \\
\hline
\end{tabular}

\section{DISCUSSION}

When dealing with themes as complex as quality of life and populational aging, one cannot consider them as separated from other important subjects, such as sexual life and HIV/AIDS, not to mention other factors which are also very important regarding HIV infections, such as socio-historical context, social representations and economic condition. All of that interferes in the elder's life, if we treat him or her (MINISTÉRIO DA SAÚDE, 2007).

According to the results obtained in this study, it could be observed that the sample has represented the epidemiological characterization of the users of the public health system, that is: most participants are women (74\%), with low income (51\% presented an income of up to one minimum wage) and relatively low education $(34.2 \%$ related to have studied between 4 and 7 years), just as it happens in the study of Silveira and Paskulin (2014), where $51.2 \%$ of the sample was composed of females, $79.6 \%$ of which received a retirement pension, and $77 \%$ had studied up to 8 years. Paulino et al (2014) has also presented similar numbers in a study, being that his sample was composed by $62.1 \%$ of female participants, $57 \%$ earned up to one minimum wage, and $70 \%$ of the participants' education was composed of basic school alone. According to the Brazilian Institute of Geography and Statistic (2010), there is a ratio of 96 men for each 100 women in Brazil, and this greater number of women can justify the findings of the research, and that most of its participants are female.

A study conducted by Nascimento et. al (2013) has indicated that most elders $(45.4 \%)$ have studied between 4 and 7 years, $48.7 \%$ presented income of between 1 and 3 minimum wages, $65.1 \%$ of them said they were practicing catholics, and $57.4 \%$ alleged not to have a partner (a). The present research has found very similar results, according to which $34.2 \%$ of the participants have studied between 4 and 7 years, $51 \%$ had an income from 1 to 3 minimum wages, and $63.6 \%$ of them are 
practicing catholic. The only variable which is different is the one about having a partner (a), in which most male elders $(68.1 \%)$ stated to have a partner, while $59.2 \%$ of females said not to have one.

When considering the elders' perception regarding the ways through which one could be contaminated by HIV/AIDS, the question about transmission through the sharing of syringes was the one with the best right answer ratio. That finding corroborates those of other researches with this theme (LOZZAROTTO 2008; PRADO, 2014). A reason for those results might be related to the history of the disease, which, since it was discovered, has a direct connection to vulnerable groups, in this case, to drug users, since the fact that they can be contaminated through sharing needles and syringes has been incessantly divulged by campaigns made by the Ministry of Health, even though those campaigns might not have been targeted at elders.

It is known that mosquitoes are not capable of transmitting the disease since the 1980s (HEBERT, 1986). However, when questioned about transmission through mosquito bite, a significant number o participants $(45.7 \%)$ stated that this type of transmission it is possible. A study conducted in 2013, by Nascimento et al., has found similar results to those of this study, where $47.4 \%$ of respondents stated to believe that mosquitoes are vectors for HIV. By its turn, a research conducted by Pereira in 2010 showed as a result that $79.6 \%$ of respondents believed that transmission was possible through mosquito bites.

The Ministry of Health, in its Clinical Protocol and its Therapeutic Directives for the Managing of the HIV Infection in Adults, states that an infection by HIV can present an ample variety of clinical symptoms, manifested or not from the acute phase of the disease, up to the advanced phase, which is considered to be the AIDS itself (BRASIL, 2013); those effects that the infection has on the individual's body relate directly to the way in which their organism and immunological system react to the virus (NGUYEN, 2003), which are determined by the amount of TCD4 + lymphocytes. That being so, contamination by the HIV virus will not cause the AIDS disease immediately, its manifestations and symptoms being visible when the immune system presents weakness, with T CD4+ rates below 500 cells/ml (PARHAM, 2001; ABBAS, 2000). When questioned about the clinical presentation of the disease, less than half of the participants (41.5\%) stated that the symptoms are not always manifested, being that the men $(49.6 \%)$ had a higher wrong answer percentage. In a study conducted in one primary health care unit in Belém-PR, about $58 \%$ of the participating elders stated that a person with the virus will always manifest the symptoms of the disease (NASCIMENTO, 2013). Still regarding the same theme, a research conducted at the Vale dos Sinos has found that $49.4 \%$ of the participants gave the same answer (LOZZAROTTO, 2008).

After years o beliefs and taboos, the HIV/AIDS disease was demystified, no longer being understood as a disease that affects only specific or restrict groups, but as a universal one, which do not choose race, culture, socioeconomical conditions, neither does it choose a specific age group; HIV/AIDS relates directly to behavioral practices, such as the unprotected sexual intercourse with multiple partners, not to mention the sharing of needles and syringes, and in certain cases, nowadays rare, of transplants and blood donation (BATISTA, 2011, BITTENCOURT, 2015, COSTA, 2012).

A significant part of the respondents $(86.3 \%)$ seem to understand the universality of the disease, as they recognize that it is not a disease that only affects "risk groups", and $88.1 \%$, when asked about whether there are risks for the population of older age groups, believe that they should be worried about the disease. A study published in 2013 with 310 elders from both genders who live in a community in Belém do Pará, has found numbers which are similar to those of this research, being that $67.4 \%$ of the participants have highlighted that elder people should worry about AIDS (NASCIMENTO, 2013). In a study published in 2012, which investigated 243 elders in a community in Arcoverde, Pernambuco, has found that $50 \%$ of the elders recognize that they still need to worry about AIDS (COSTA, 2012).

Another study present similar results when compared to this research, since almost $100 \%$ of its respondents recognized that the elder is still under the risk of contagion, thus demystifying the belief common in the general population, that the AIDS disease still belongs to a specific risk group. The gaps in these beliefs can be attributed to taboos regarding sexuality in old age, taboos which result in few campaigns aimed at the elderly, not to mention the incapability of professionals of our society to discuss the subject of HIV/AIDS with the elderly, bringing about serious consequences to the population, such as the little knowledge the elders have regarding the infection by HIV, and the belief that they are immune (GARCIA, 2012).

On the other hand, the conscience of the risks to which they are exposed has not made the respondents feel like they needed to undergo an 
AIDS test, being that $49.6 \%$ of men and $62.4 \%$ of women have never undergone it. That was also true in other studies which aimed at acquiring such information, where 91\% (LOZZAROTO, 2013) and 91.6\% (NASCIMENTO, 2013) of elders were found to have never undergone the AIDS test.

Researches presented ample knowledge regarding the use of condoms to prevent the transmission of the virus $(89.4 \%)$, which corroborates previous researches (BITTENCOURT, 2015; LOZZAROTTO, 2013; PRADO, 2012), according to which the elders recognize the condom as a way to prevent contamination; however, over $80 \%$ of the elders of both genders stated not to use the condom when in a sexual intercourse. Probable explanations for this are the high number of females in the research, the high number of sexual inactivity mentioned, and the number of elders who have partners.

Since this study was conducted with people of an older age group, it can be inferred that the women have already been through the postmenopause stage. That eliminates the risk of a pregnancy, and they no longer believe the use of a condom is necessary to prevent STDs, since usually the male condom is seen mostly as contraceptive method (BATISTA, 2011; INELMEN, 2005; LOZZAROTTO, 2008). The difficulty of female empowerment is also a factor, as it may transform the decision of using a condom or not an unilateral choice, where only the man can take this decision (MELO, 2012); the existence of a sTable partner, can also lead to the belief that preventive measures are not necessary (BITTENCOURT, 2015). These statements corroborate with this study, which is noticeable through the high number of women $(88.2 \%)$ who answered no to the question regarding the use of the condom. The same result was found in the research conducted by LOZZAROTTO in 2013, with people older than $60 \mathrm{y} / \mathrm{o}$, in which the population was represented by $83 \%$ of females, and $84 \%$ stated not to use the condom. Among men, the prejudice against the use of the condom is maintained, as well as statements indicating that they sometimes do not have a condom with them when needed, and that their pleasure is reduced when it is used during sexual intercourses (BITTENCOURT, 2015).

The choice not to use a condom brings about serious consequences to the individuals. In a study which analyzed people older than $50 \mathrm{y} / \mathrm{o}$ diagnosed with HIV, $90.8 \%$ have stated not to have used condoms in their sexual intercourses (LIMA, 2012). The Ministry of Health, in its campaigns since the decade of 1980 , clarifies that the main form of prevention against contagion by the HIV virus is the use of the condom, be it a male or female condom, both of which can be found gratuitously in primary health care units in any city (BRASIL, 2013).

The view of the elderly as asexual beings has been demystified in the last years (PASCUAL, 2002); the affective relationships among people older than $60 \mathrm{y} / \mathrm{o}$ have become stronger, not to mention the changes in the sexual profile of the elders, which are a consequence of the improvements of the health process and in the quality of life (BITTENCOURT, 2015). With the sexuality still surfacing at an old age and the lack of use of preventive measures, the number of cases of AIDS in this population increases (BRASIL, 2010; GODOY, 2008).

Regarding the question "aiming at acquiring knowledge about the sex life", a greater percentage of men with an active sexual life was found (92.4\%), almost twice the number of women (57.7\%). In a research, Melo (2012) has verified that $80 \%$ of the elderly interviewed stated to have an active sex life, while Pereira (2010) found a result of $46.2 \%$ of elders to be sexually active.

Sexual activity involves several factors, from physiological changes presented by the body as it ages, to cultural and psychological aspects, marital status, as well as societal judgments (ALENCAR, 2014).

Intrinsic and extrinsic factors influence both genders according to their particularities. Most of women, after they lose a partner, do not engage in a new relationship. After menopause, the hormonal and ovarian changes make it so their skin become dry and thin, and provoke a diminishing of vaginal lubrication, which leads to sexual discomfort and dyspareunia. The vaginal contractions also get weaker and less frequent, which makes the orgasm more difficult to achieve, and also makes it last for less time (POLIZER, 2009), which make the sexual act more difficult for female elders. In this study, it was found that $69.2 \%$ of women were not interested in have sexual intercourses more times, in other days or when given other opportunities. The unfavorable sex in female elders is once again reaffirmed by the study as it indicates that $64 \%$ of the interviewed report their sexual intercourses as being bad or null, corroborating with another research which found a meaningful number of female elders referring to sexual activities as bad or null when compared to the male elders (SANTOS, 2014). Another research aimed at knowing the female sexual satisfaction in the old age, found that $67 \%$ of them related it to be null (SILVA, 2011). 
About the physiological changes faced by elder men, they are characterized by flaccid erections, retardation of climax and ejaculation, as well as a diminishing in the pre-ejaculatory liquid. However, the male elders are not affected by extrinsic factors as the female are, not to mention the existence of resources to minimize the physiological factors (ALENCAR, 2014). Only $7.6 \%$ of the respondents presented bad or null sexual activities, and the greatest score was in the statements varying from good to excellent. This percentage can also be attributed to the cultural necessity of men in any age group to reaffirm their sexuality. This is corroborated by a study which investigated the sex life of adult, young, and elder men, in which $62.9 \%$ and $80 \%$ of the people in the research related to be sexually active (MELO, 2012). In a research conducted by Batista (2011), which investigated the sex life of men in an old age, it was found that only $3.3 \%$ of the participants stated to have an inactive sex life.

Sexuality is a part of every step of the vital cycle. Thus, the elders are not less sexual, neither are they devoid of sexuality. The beliefs and taboos that surround an elder sex life bring about serious consequences to society, and raise obstacles which lead to the disregard of the sexuality of the elderly (BRASIL, 2010; GODOY, 2008; SILVEIRA, 2011).

It is important to highlight that, even though some questions had a high ratio of right answers, doubts and mistakes regarding HIV/AIDS are still
MALAQUIAS, B. S. S. et al.

evident in this population. It is known that nowadays campaigns are being created to reach those groups of people, even if intertwined to other age groups. It is, however, necessary to create campaigns and public policies which specifically target the elderly, campaigns which use adequate means to reach this population. It is necessary to fight those beliefs and taboos, as the sexuality of people above $60 \mathrm{y} / \mathrm{o}$ is becoming more and more evident, which puts this population under the risk of transmitting and/or being contaminated by the HIV virus.

The results of this research point at the need to make health professionals aware of the situation, as they are responsible for sensitizing the population regarding adequate health conducts, and can offer subsidies for the elderly population to approach the subject of sexuality and HIV/AIDS, aiming at sensitizing them to the risks they are being exposed to.

Not to discuss sexuality in the old age can bring about mistakes, such as elders who still perform sexual acts without preventive measures, and are in fact under the risk of contracting HIV/AIDS and other sexually transmitted diseases. Thus, it is necessary to raise awareness regarding this issue, especially among health professionals, and to create an arsenal of public policies which can guarantee the demystification of beliefs regarding sex life in the old age, guaranteeing that the elders can have a conscious, healthy, and dignified sex life.

RESUMO: O objetivo deste estudo foi analisar o conhecimento de idosos acerca do HIV/AIDS e o quociente sexual de ambos os sexos num Centro de Convivência de uma cidade do interior de Minas Gerais. Trata-se de um estudo descritivo, transversal e quantitativo envolvendo 457 idosos participantes de grupos de convivência da Unidade de Atenção ao Idoso (UAI) do Município de Uberaba -MG. Neste estudo aplicou-se os instrumentos: MEEM para elegibilidade da cognição mínima, QHIV3I para avaliação do conhecimento e, QS-F/QS-M para mensuração do quociente sexual. Para análise dos dados utilizou-se "Statiscal Package for Social Sciences" (SPSS) versão 20.0. O sexo feminino representou $74 \%$, com 40,5\% na faixa etária entre 70 a 79 anos, 51,8\% afirmaram não possuir parceiro. O maior índice de acertos foi encontrado no quesito transmissão, como por seringa e agulhas 96,2\%. Já nos erros foi na resposta de transmissão através de mosquito com apenas $45,1 \%$ de acertos. Do total de idosos, 90,2\% sabem que é possível detectar o vírus através de exames laboratorial. E, 88,2\% deles relataram nunca terem usado camisinha durante as relações sexuais. Do quociente sexual $57,7 \%$ das idosas afirmaram ter vida sexual ativa nula ou ruim, enquanto os idosos com vida sexualmente inativa foram apenas 7,6\%. São necessárias campanhas voltadas exclusivamente para tal público, bem como, a conscientização de profissionais da saúde, tornando possível o reconhecimento da sexualidade do envelhecido e os riscos inerentes a ela.

PALAVRAS- CHAVE: Sexualidade. HIV. Idoso.

\section{REFERENCES}

ABBAS, A. K.; LICHTMAN, A. H.; POBER, J. S. Cellular and molecular immunology.4.ed. Philadelphia: W. B. SaundersCompany, 2000. 553p. 
ABDO, C. H. N. Elaboração e validação do quociente sexual - versão masculina, uma escala para avaliar a função sexual do homem. RevBras Med. v. 63, n. 1-2, p. 42-46, 2006.

ABDO, C. H. N. Elaboração e validação do quociente sexual - versão feminina, uma escala para avaliar a função sexual da mulher. RevBras Med. v. 63, n. 1-2, p. 670-672, 2006.

ALENCAR, D. L.; MARQUES, A. P. O.; LEAL, M. C. C.; VIEIRA, J. C. M. Fatores que interferem na sexualidade de idosos: uma revisão integrativa. Ciência Saúde Coletiva, Rio de Janeiro, v. 19, n. 8, p. 35333542, 2014. Disponível em: http://www.scielo.br/pdf/csc/v19n8/1413-8123-csc-19-08-03533.pdf. Acesso em: 5 fev. 2016.

BATISTA, A. F. O.; MARQUES, A. P. O.; LEAL, M. C. C.; MARIANO, J. G.; MELO, H. M. Idosos: Associação entre o conhecimento da aids, atividade sexual e condições sociodemográficas. Rev. Bras. Geriatr. Gerontol, Rio de Janeiro,v. 14, n. 1, p. 39-48, 2011. Disponível em: $<$ http://www.scielo.br/scielo.php?script=sci_arttext\&pid=S1809-98232011000100005>. Acesso em: 28 jan. 2016.

BEAUDLAURIER, R. L.; CRAIG, S. L.; DE LA ROSA M. Older Latina women and HIV/AIDS: an examination of sexuality and culture as they relate to risk and protective factors. J GerontolSocWork [Internet]. v. 52, n. 1, p. 48-63, 2009. Disponível em:<http://www.ncbi.nlm.nih.gov/pmc/articles/PMC2693918/>. Acesso em: 1de mai.2014.

BITTENCOURT, G. K. G. D.; MOREIRA, M. A. S. P.; MEIRA, L. C. S.; NÓBREGA, M. M. L.; NOGUEIRA, J. A.; SILVA, A. O. Beliefs of older adults about their vulnerability to HIV/Aids, for the construction of nursing diagnoses. RevBrasEnferm, Brasília-DF, v. 68, n. 4, p. 579-585, 2015. Disponível em: $<$ http://dx.doi.org/10.1590/0034-7167.2015680402i >. Acesso em: 23 jan. 2016.

BRASIL, Ministério da Saúde. Secretaria de Vigilância em Saúde. Departamento de DST/Aids e Hepatites Virais. Boletim epidemiológico Aids e DST [Internet]. 2010. Disponível em: <http://www.aids.gov.br/pagina/2010/36374>. Acesso em: 23 jan 2016.

BRASIL. Ministério da Saúde. Departamento de Atenção Básica. Envelhecimento e saúde da pessoa idosa. Secretaria de Atenção à Saúde. Brasília, 2007. Disponível em: <http://bvsms.saude.gov.br/bvs/publicacoes/abcad19.pdf>. Acesso em: 11 nov. 2015.

BRASIL. Ministério da Saúde. Departamento de Atenção Básica. Envelhecimento e Saúde da Pessoa Idosa. Secretaria de Atenção à Saúde. Brasília: Ministério da Saúde, 2007.

BRASIL. Instituto Brasileiro de Geografia e Estatística. IBGE: população brasileira envelhece em ritmo acelerado [internet] 2010. Disponível em:

$<$ http://www.ibge.gov.br/home/presidencia/noticias/noticia_visualiza.php?id_noticia=1272 >. Acesso em: 02 fev. 2016.

BRASIL. Ministério da Saúde. Protocolo clínico e diretrizes terapêuticas para manejo da infecção pelo HIV em adultos. Secretaria de Vigilância em Saúde. Brasília, 2013. Disponível em: <http://www.aids.gov.br/sites/default/files/anexos/publicacao/2013/55308/protocolo_final_31_7_2015_pdf_30 707.pdf>. Acesso em: 16 jan. 2016.

CIOSAK, S. L.; BRAZ, E.; COSTA, M. F. B. N.; NAKANO, N. G. R.; RODRIGUES, J.; ALENCAR, R. A.; ROCHA, A. C. A. L. Senescência e senilidade: novo paradigma na Atenção Básica de Saúde. Rev Esc Enferm USP. São Paulo, v. 45, n. 2, p. 1763-1768, 2011.

COSTA, A. P.; COSTA, C. P. J.; ALBUQUERQUE, S. C. O conhecimento de HIV/AIDS entre os idosos da Unidade de Saúde da Família João Pacheco Freire Filho, Arcoverde. Saúde Coletiva em Debate, 
Pernambuco,v.2, n. 1, p. 09-19, dez. 2012. Disponível:

<http://fis.edu.br/revistaenfermagem/artigos/vol02/artigo04.pdf >. Acesso em: 20 fev. 2016.

FLEURY, H. F.; ABDO, C. H. N. Importância do apoio psicoterapêutico para disfunção sexual no envelhecimento. Diagn Tratamento. São Paulo, v. 16, n. 4 p. 161-3, 2013.

GALATI, M. C. R; ALVES JR., E. O.; DELMASCHIO, A. C. C., HORTA, A. L. M. Sexualidade e qualidade de vida em homens com dificuldades sexuais. Psico-USF. Itatiba, v. 19, n. 2, p. 242-52, 2014 . Disponível em: <http://www.scielo.br/scielo.php?script=sci_arttext\&pid=S1413-82712014000200007>. Acesso em: 14 julh. 2015.

GARCIA, G.; LIMA, L.; SILVA, J. B.; ANDRADE, L. D. F.; ABRÃO, F. M. Vulnerabilidade dos idosos frente ao HIV/aids: Tendências da Produção científica atual no brasil. DST - J Bras Doenças Sex Transm., Rio de Janeiro, v. 24, n. 3, p. 183-188, 2012. Disponível em: < http://www.dst.uff.br/revista24-3-2012/7Vulnerabilidade_idosos_aids.pdf>.Acesso em: 20 fev. 2016.

GODOY, V. S.; FERREIRA, M. D.; SILVA, E. C.; GIR, E.; CANINI, S. R. M. S. Epidemiological profile of Aids in elderly patients using DATASUS Helyh Information: realities and challenges. DST J Bras Doenças Sex Transm., Rio de Janeiro, v. 20, n. 1, p. 7-11, 2008. Disponível em:< http://www.dst. uff.br/revista20-12008/1.pdf Portuguese>.Acesso em: 1 fev. 2016.

KALACHE. A.; VERAS, R. P.; RAMOS, L. R. O envelhecimento da população mundial: um desafio novo. Rev. Saúde Pública [online]. v. 21, n. 3, p. 200-10, 1987. Disponível em: <http://www.scielo.br/pdf/rsp/v21n3/05.pdf>. Acesso em: 14 Julh. 2015.

LIMA, T. C.; FREITAS, M. I. P. Health Behavior in a population with HIV/Aids. RevBrasEnferm. BrasíliaDF, v. 65, n. 1, p. 110-115, 2012. Disponível em: <http://www.scielo.br/scielo.php?script=sci_art text\&pid=S0034-71672012000100016>. Acesso em: 01 fev. 2016.

LOZZAROTTO, A. R.; KRAMER, A. S.; HADRICH, M.; TONIN, M.; CAPUTO, P.; SPRINZ, E. O conhecimento de HIV/aids na terceira idade: estudo epidemiológico no Vale do Sinos, Rio Grande do Sul, Brasil. Ciênc Saúde Coletiva, Rio de Janeiro, v. 13, n. 6, p. 1833-1840, 2008 . Disponível em: $<$ http://www.scielo.br/scielo.php?script=sci_arttext\&pid=S1413-81232008000600018>. Acesso em: 15 jan. 2016.

LOZZAROTTO, A. R.; SANTOS, S. S.; REICHERT, M. T.; QUEVEDO, D. M.; FOSSATTI, P.; SANTOS, G. A.; CALVETTI, P. U.; SPRINZ, P. Oficinas educativas sobre HIV/Aids: uma proposta de intervenção para idosos. Rev Bras Geriatr Gerontol. Rio de Janeiro, v. 16, n. 4, p. 833-843, 2013. Disponível em: < http://www.scielo.br/pdf/rbgg/v16n4/1809-9823-rbgg-16-04-00833.pdf>. Acesso em: 21 fev. 2016.

MELO, H. M. A.; LEAL, M. C. C.; MARQUES, A. P. O.; MARINO, J. G. O conhecimento sobre Aids de homens idosos e adultos jovens: um estudo sobre a percepção desta doença. Ciênc Saúde Coletiva. Rio de Janeiro, v. 17, n. 1, p. 43-53, 2012. Disponível em: <http://www.scielo.br/pdf/csc/v17n1/a07v17n1.pdf >. Acesso em: 29 jan. 2016.

NASCIMENTO, R. G; MONTEIRO, E. L; FERREIRA, L. S.; SANTOS, Z. N. L. Nível de conhecimento de idosos comunitários em relação ao HIV/Aids: estudo exploratório na rede básica de saúde de Belém, Pará, Brasil. RBCEH. Passo Fundo, v. 10, n. 1, p. 113-122, jan./abr. 2013. Disponível em:<http://www.perguntaserespostas.com.br/seer/index.php/rbceh/article/view/3018/pdf> .Acesso em: 02 fev. 2016.

NGUYEN, N.; HOLODNIY, M.; HIV infection in theelderly. ClinInterv Aging.v.3, n.3, p. 453-472, 2008.Disponível em: < http://www.ncbi.nlm.nih.gov/pubmed/18982916>. Acesso em: 15 jan 2016.

PAUL, W. E. Fundamental immunology. 7 ed. Philadelphia, 2012. 1312 p. 
PARHAM, P. O sistema imune. Porto Alegre: Artmed, 2001. 372 p.

PASCUAL, C. P. A sexualidade do idoso vista com novo olhar. São Paulo: Edições Loyola, 2002. 165 p.

PAULINO, M. C. F.; BERNARDES, C. A.; SOUZA, L. P. S.; FONSECA, A. D. G., PINHEIRO, M. Â. M.; SILVA, C. S. O.; MOTA, É. C. Análise dos comportamentos sexuais de idosos cadastrados em uma Estratégia Saúde da Família. Rev Kairós Geront. São Paulo, v. 17, n. 4, p. 49-61, dez. 2014. Disponível em: <http://revistas.pucsp.br/index.php/kairos/article/view/23396/16829 >. Acesso em: 02 fev. 2016.

PEREIRA, G. S.; BORGES, C. I. Conhecimento sobre HIV/AIDS de participantes de um grupo de idosos, em Anápolis-Goiás. Esc Anna Nery. Rio de Janeiro, v. 14, n. 4, p. 720-725, 2010. Disponível em: $<$ http://www.scielo.br/scielo.php?script=sci_arttext\&pid=S1414-81452010000400010 >. Acesso em: 15 jan 2016.

POLIZER, A. A.; ALVES, T. M. B. Perfil da satisfação e função sexual de mulheres idosas. Fisioter Mov. Curitiba, v. 22, n. 2, p. 151-158, 2009. Disponivel em: < http://www2.pucpr.br/reol/public/7/archive/000700002698-ART01.PDF>. Acesso em : 10 fev 2016.

PRADO, J. P.; NEVES, E. F.; SILVA, G. S.; SILVA, I. C. R. O conhecimento de HIV/AIDS em idosos de uma comunidade carente do Distrito Federal. Acta Ciênc Saúde. Taguatinga Sul, v. 1, n. 2, p. 87-101, 2012. Disponível em: <http://www.ls.edu.br/actacs/index.php/ACTA/article/view/45>. Acesso em: 15 jan 2016.

SANTOS, D. S. D. S.; ROCHA, L. F.; LACERDA, L. S.; RAMOS. P. C. Opinião de homens e mulheres idosos sobre a vida sexual na velhice. $14^{\circ}$ Congresso Nacional de Iniciação Cientifica. 2014.

SÃO PAULO (Estado). Secretaria Saúde de São Paulo. Documento de Diretrizes para prevenção das DST/AIDS em idosos. Bepa. v. 8, n. 92, p. 15-35, 2011.

SILVA, M. R. A. Satisfação e função sexual em mulheres idosas participantes de um grupo de convivência. 2011. 93 f. Dissertação (Mestrado em Saúde Coletiva) - Universidade Federal de Pernambuco, Recife, 2011. Disponível em:

<http://repositorio.ufpe.br:8080/bitstream/handle/123456789/9174/arquivo3395_1.pdf?sequence=1\&isAllowed =y>. Acesso em: 18 jan. 2016.

SILVEIRA, M. M.; BATISTA, J. S.; COLUSSI, E. L.; WIBELINGER, L. M. Sexualidade e Envelhecimento: discussões sobre a AIDS. Rev Kairós Geront. São Paulo, v. 4, n. 5, p. 205-220, 2011.

SILVEIRA, G.; WITTKOPF, P. G.; SPERANDIO, F. F.; PIVETTA, H. M. F. Produção científica da área da saúde sobre a sexualidade humana. Saúde Soc. São Paulo, v. 23, n. 1, p. 302-312, 2014 . Disponível em:<. http://dx.doi.org/10.1590/S0104-12902014000100024.nrm=iso >Aacesso em: 14 julh. 2015.

SILVEIRA, V. C.; PASKULIN, L. Perfil e rede de apoio de idosos internados na emergência do hospital de clínicas de Porto Alegre. Estud Interdiscipl Envelhec. Porto Alegre, v. 19, n. 2, p. 377-396, 2014. Disponível em:<http://www.seer.ufrgs.br/RevEnvelhecer/article/view/40025>. Acesso em: 03 fev. 2016. 